
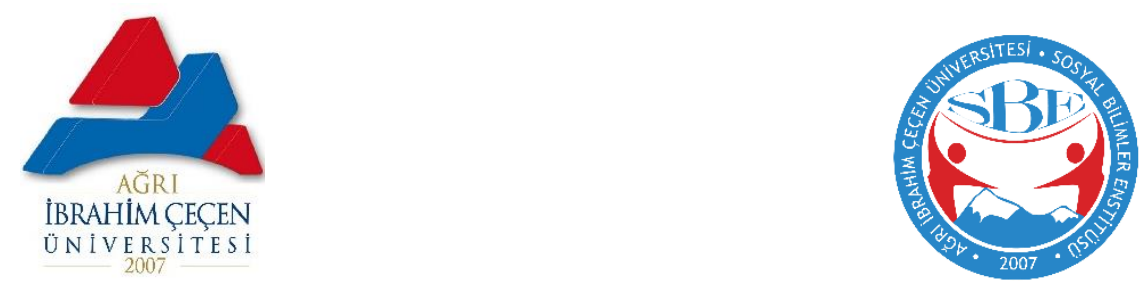

BERAT ALANYALI'NIN BOZKIR GECESINDE BIR TREN ADLI ESERINE TEMATIK AÇIDAN GENEL BIR BAKIŞ

A General Review On Work Of Berat Alanyalı Bozkır

Gecesinde Bir Tren In Thematic Aspects

\title{
Büşra YALNIZ
}

Ağrı ibrahim Çeçen Üniversitesi

Bbsraylnz993@gmail.com.tr

iD https://orcid.org/0000-0003-3707-1331

\section{Dr. Öğr. Üyesi Alpay GEZER}

Ağrı Ibrahim Çeçen Üniversitesi Fen Edebiyat Fakültesi Türk Dili ve Edebiyatı Bölümü

alpaygezer@hotmail.com
https://orcid.org/0000-0001-8773-1559
Ağrı ibrahim Çeçen Üniversitesi Sosyal Bilimler Enstitüsü Dergisi-
Journal of Ağrı ibrahim Çeçen University Social Sciences Institute-
AicuSBED 7/l Nisan /April 2021 / Ağrı
ISSN: 2149-3006





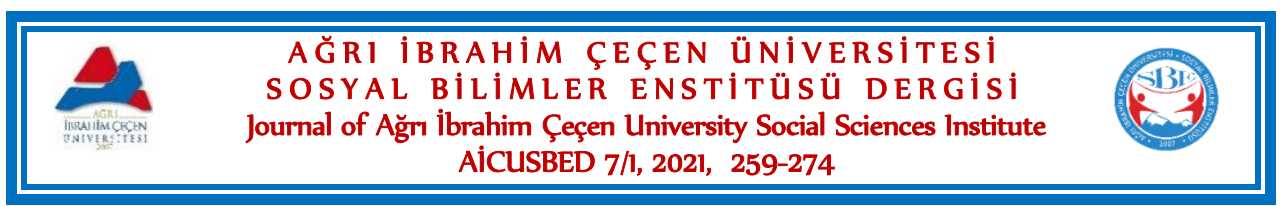

BERAT ALANYALI'NIN BOZKIR GECESINNDE BIR TREN ADLI ESERİNE TEMATIKK AÇIDAN GENEL BİR BAKIŞ

A General Revıew on Work of Berat Alanyalı Bozkır Gecesinde Bir

\title{
Tren in Thematic Aspects
}

Büşra YALNIZ - Dr. Öğr. Üyesi Alpay GEZER

$\ddot{O} \mathbf{z}$

$\mathrm{Bu}$ çalışmada öykü türüyle eserler veren Berat Alanyalı'nın Bozkır Gecesinde Bir Tren adlı kitabı tematik açıdan incelenecektir. Çalışmanın amacı, Alanyalı'nın Bozkır Gecesinde Bir Tren adlı eserini tanıtmaktır. Çalışmamızda öncelikle öykü ve küçürek öykü türüne değinilecek, sonrasında Alanyalı'nın inceleme konusu olan eserinin değerlendirmesine yer verilecektir. Öykü, Berat Alanyalı'nın duygularını ve düşüncelerini derinden sunduğu bir türdür. Yazar duygularını sunarken duru, akıcı ve canlı üslubuyla da eserlerini daha etkileyici hâle getirmiştir. Tema yönünden zengin bir kitap olan Bozkır Gecesinde Bir Tren'de umut, yalnızlık, özlem ele alınan birkaç temadan biridir. Öykülerinde farklı türdeki anlatım tekniklerinden de faydalanan yazar eserini bu teknikler sayesinde tekdüzelikten uzaklaştırmıştır. Eserindeki kahramanların birçoğunu kadınlardan seçen Alanyalı, hayatın farklı yönlerini bu kadınlar üzerinden anlatmayı tercih etmiştir. Kişilerini tek boyutlu ele almamış ve her kesimden insanın hayatını da eserine konu etmiştir. Etkileyici bir anlatıma sahip olan kitapta metaforlar da kendini göstermektedir.

Anahtar Kelimeler: Berat Alanyalı, öykü, küçürek öykü, metafor, kadın.

\begin{abstract}
In this study, story writer Berat Alanyalı's Bozkrr Gecesinde Bir Tren will thematically be examined.The purpose of this essay is to introduce her work, Bozkir Gecesinde Bir Tren. In this work, I will firstly mention about the terms story and short story, afterwards a review on her examined work will be included. Narrative is the genre that deeply presents her emotions and her opinions. The author makes her works more impressive with her pure, fluent and vivid style while expressing her feelings. Hope, solitude and longing are one of the themes presented in the novel Bozklr Gecesinde Bir Tren which is rich in themes. Making use of different types of literary devices in her stories, the author saves her work from monotony thanks to those literary devices. Making most of the heroes in her work women, Alanyall chose to depict the unusual aspects of life through those women. Not making her characters one-
\end{abstract}

http://dergipark.gov.tr/aicusbed 7/1 Nisan/April 2021 
dimensional, she also make people from all parts of life as her subject. Metaphors are also included in the novel having impressive narration.

Key Words: Berat Alanyal1, story, short story, metaphor, women.

\section{Giriș}

Öykü sözcügü taklit etmek, benzemek anlamlarına gelmektedir. Hikâye kelimesine karşılık olarak kullanılan öykü sözcügünün onun yüzyıllar boyuna kullanılan anlam zenginliğini pek karşılamadığı görülmektedir. Daha çok kısa hikâye için kullanılan öykünün zamanla hikâye kavramının yerini alacağı gözlemlenmektedir (Kolcu, 2018: 15).

Temelinde simgesel, yoğun ve özgün bir anlatım söz konusu olan küçürek öykü, öykünün alt kolu olup 20. yüzyılın son dönemlerinde ortaya çıkmış bir türdür. Dünya edebiyatında “ilk çok kısa öykü derlemeleri 1960'lı y1llarda Robert Coover'ın çıkardığı TriQuarterly'nin 'Küçük Öyküler' özel sayısında yayımlanmıştır" (Shapard, 1997: 92). Zamanla gelişmeye ve yaygınlaşmaya başlayan türün önde gelen isimleri Julio Cortázar, Dino Buzzati, Franz Kafka, Eduardo Galeano, Max Jacob gösterilebilir. Türk edebiyatında 1990'l1 yıllardan itibaren etkisi artmaya başlayan türün gelişimine Ferit Edgü, Rasim Özdenören, Sevinç Çokum, Necati Tosuner, Refik Algan, Tezer Özlü gibi birçok yazar katkı sağlamıştır.

Ramazan Korkmaz bu nitelikteki öyküyü tanımlamak için: " 250 veya 500 sözcük, çığlığı nağmeye dönüştürmek için yeterli süreyi hazırlayan bir anlatım örgüsü oluşturur. Bu bakımdan 100 sözcüğü geçmeyecek anlatıları ancak küçürek öykü diye adlandırabiliriz" (Korkmaz, 2007: 19) diyerek bu türün tanımını yapar. Küçürek öykünün Türk edebiyatındaki önemli temsilcilerinden olan Ferit Edgü ise küçürek öykü için: "Yalnızca bir anın saptaması olan öykücükler" (Edgü, 1997: 12) şeklinde bir değerlendirme yapmıştır.

Hızlı tüketim çağının ürünlerinden biri olan küçürek öyküler, kısa bir hacme ve yoğun bir anlatıma sahiptir. Bu tür öykülerde olay genellikle komprime bir vaziyettedir ve onun ayrışımı okuyucunun birikimine bırakılır. "Küçürek öyküde yazar pek çok şeyi uzun uzun anlatmak zorunda değildir. Okuyucunun zaten bildiği bir şeyleri ima ederek geçer ve pek çok ayrıntıyı anlatmaz; öyküde eksik bırakılan noktaları okurun tamamlamasını bekler. Bu bakımdan küçürek öykülerde okura da çok iş düştügünü söylemek gerekir. Küçürek öykülerde yazar, şiirde olduğu gibi çoğu zaman imgeler kurar ve onların gücünden faydalanarak hikâyesini anlatır” (Yumuşak, 2013: 6).

Berat Alanyalı, hem incelemeye esas aldığımız Bozkır Gecesinde Bir Tren adlı kitabında hem de diğer öykü kitaplarında küçürek öykü türünü sıklıkla kullanmıştır. Bozkır Gecesinde Bir Tren kitabında bulunan "Bütün Kara 
Parçalarında", "Gökyüzü Gibi”, "Bana Keman Çal”, "Gazi”, “Üvey”, "Kayıp”, "Aşkların Eski Tadı Yok", "Son Yolcuyu Beklerken”, "Başucu Dilekleri” bu türle yazılmış olan öykülerdir. Bozkır Gecesinde Bir Tren adlı eserdeki tüm öykülerden yola çıkarak yazarın öykücülüğünün vurgulanması ele alınan konulardandir.

\section{Bozkır Gecesinde Bir Tren}

Bozkır Gecesinde Bir Tren, Berat Alanyalı'nın ilk öykü kitabıdır. Yazar tarafından 2007 yılında Tin Kovuğu adı ile yayımlanır. Bir sonraki basımda ise kitabın adı Bozkır Gecesinde Bir Tren olarak değiştirilir.

Yazar kitabın adının değişmesi ile ilgili düşüncelerini şu sözlerle ifade eder: "Öykü yolculuğumun ilk ürünü yeniden basıma hazırlanırken kimi öykülerimi gözden geçirdim ve Tin Kovuğu adıyla vedalaştım. Bozkır Gecesinde Bir Tren... Sanırım daha iyi. Yürekle metin arasında işleyen hassas ölçek böyle söylüyor" (Alanyalı, 2017: 5). ${ }^{1}$

Yirmi üç öykünün bulunduğu Bozklr Gecesinde Bir Tren adlı kitapta küçürek öyküler de mevcuttur. Bunun da etkisiyle kitap yoğun bir anlatıma sahiptir. Kitaptaki her öyküde farklı bir durum anlatılmaktadır. En son öykü olan "Tin Kovukları"nda ise kitaptaki diğer öykülerin kahramanları bir trende karşılaşır.

Yazar, öykülerinde kadın kahramanları ön plana çıkarmıştır. Kitaptaki öykülerin birçoğunun başkahramanı kadındır. Bu kadınların kimi acılı kimi yalnız kimisi ise güçlüdür. Ayrıca öykülerde mekân, zaman gibi unsurlardan çok kişilerin iç dünyası üzerinde durulmuştur.

\footnotetext{
${ }^{1}$ Yazar, Dilek Atll ile yaptı̆̆ı söyleşide konuyla ilgili şunları da söyler: "Çok sevdiğim Tin Kovuğu adı, kayıplarımızın içimizde bıraktığı boşluğu ifade ediyordu ve öykülerde bir karşılı̆̆ı vardı. Ancak bu isim ender olarak doğru anımsanıp söylenebildi. Tin Kavuğu, Tan Kabuğu benzeri söylemler, bu adın yaşama tutunamadığını gösterdi bana. Bu ada ilk eleştiriyi yapan değerli Mustafa Şerif Onaran çok haklıymış, ruhu şad olsun. Kitabımın çıktığı yıl, Ankara Öykü Günleri'nde tanışmıştık. Bana neden okurun hemen anlayıp benimseyeceği bir isim seçmediğimi sormuştu. Yeniden basım söz konusu olduğunda, ismi üzerine çok düşündüm. Sonra öyküleri bütünleyen, kitabın esprisini destekleyen bir çatı olarak Bozkır Gecesinde Bir Tren adı öne çıktı. Şimdi bu adı daha doğru buluyor ve daha çok seviyorum" (https://www.olay.com.tr/trende-birlesenyollarin-hikayesi-71950).
} 


\section{Bozkır Gecesinde Bir Tren Adı Eserde Yer Alan Öykülere Genel Bir Bakıș \\ Yolcu}

Kitabın ilk öyküsü olan "Yolcu" geçmişiyle karşılaşan bir kişiyi anlatır. Öykünün kahramanı yazar bir kadındır. Yalnız yaşayan kadın evinde çalışırken, geçmişteki kendisi çıkar gelir ve kadını izlemeye koyulur. Kadın onun geldiğini fark edince şaşırmaz ve geleceğini bildiğini söyler. Kadının gençliği ile yaşlılığı, sohbet etmeye başlarlar. Kadın zamanında vaktini iyi kullanamadığı, küçük şeylere takılıp mutlu olmayı kaçırdığı, onurlu olmayı inatçı olmayla karıştırdığı, kolayc1, sabırsız ve işine gelmeyen konularda unutkan olduğu için ona kızar. Sonra usulca yerinden kalkıp, raftan albümü alarak gençlik haline uzatır. Bebeklik günlerinden başlayan albüm, şimdiki hesaplaşma an'ını yansıtan bir fotoğrafla son bulur. "Kırlaşmış kısa saçlarıyla geleceğim, kumral kısa saçlarıyla şimdim karşılıklı oturmuş, yolumuzu gözden geçiriyorlardı." (s.12) İnsanın geçmişinden dersler alarak geleceğini şekillendirmesi gerektiğini anlatan bir öyküdür.

\section{Küller ve Lavabo}

Kitapta yer alan "Küller ve Lavabo" adlı öykü 2005 Özgür Pencere Edebiyat Derneği Kadın Öyküleri Yarışması Üçüncülük Ödülü’ne layık görülür. Öykü kendi içinde "Tarihçe, Dostluklar/şahdamarı, İkircik, Veda, Yüzleşme, Kavrayış, Şafak ve Hürleşme" adlı alt başlıklara ayrılır. Öykünün başkahramanı bir kadındır. Sevgilisi sandığı kişi tarafından yolda bırakılmış ve bu yüzden acı çeken, intihar etmeyi düşünen ve sürekli bunun planını yapan yalnız bir kadın. Kadın çektiği acıları kâğıda döküp sonrasında bunları lavaboda yakar. Geçmişindeki her şeyi temizleyip ölmek isterken babası gelir ve planlarını erteler. Kadın ölmeyi isteme konusunda çok kararsızdır. Bu kararsızlık rüyalarında da kendini gösterir ve bir gün rüyasında çuvaldızın şahdamarına batması sonucu kan kaybından ölmek üzere olduğunu görürken uyanır ve ölme isteğinden vazgeçer. Bir gece duştan çıkarken ayağı kayar ve başını lavaboya çarparak ölür. Öldükten sonra ruhu sevgilisi sandığı kişinin yanına gider ve aslında ölmeden önce ruhunun ve kadınlık gururunun o adam tarafından öldürüldügünü ve bunu aşk ile yaptığını anlar. "Katil, oydu. Maktul, kadınlık onurumdu. Zarif, işlemeli kama ise aşktl: Albenili ve ölümcül. Bana gelince... Açıkça, suç ortağıydım!” (s. 19) Kadının küllerini (geçmişini) yakıp atmak istediği yer lavabodur ve bu lavabo onu ölüme sürükleyen nesne olarak da karşımıza çıkar. Öyküde kendini çaresiz ve yalnız hisseden kadının intiharın eşiğine gelmesi ve bu yanlış düşünceden vazgeçmişken kazayla ölmesi anlatılır. Öyküde tutkunun ne kadar tehlikeli olabileceği ortaya konulmuştur. Kahraman

http://dergipark.gov.tr/aicusbed 7/1 Nisan/April 2021 
kadının boynunda çıkan küçük sivilceyi çuvaldızla delmesi de küçük şeyleri büyük şeylerle kurcalamanın oluşturduğu zararı anlatan bir metafor olarak karşımıza çıkar.

Pim

"Pim", üvey annesinin eziyetleri, babasının umursamazlığı ile büyütülmüş Peyman'ın hayatının anlatıldığı bir öyküdür. Üvey annesinden sürekli dayak yiyerek büyüyen Peyman, babasının yanına gittiği zamanlarda babası tarafından da hep geçiştirilir. Babasının sevgisini kazanmak için üvey annesine özendiği zamanlarda yine dayak yer. "Ciciannem kesti saçımı, Anne. Babam bana klzdl. Cicianneme neden kızmıyor? Onunkiler sarı diye mi? Anne, kırmızı günah mı? Babam beni beğenir sandım, Anne." (s. 21) İncinmelerle ve sevgisizlikle büyütülmüş olan bu çocuk büyüdüğü zaman bir örgüte katılır ve canlı bomba olarak bir tren istasyonunu patlatır.

Peyman'ın patlatmış olduğu istasyon kitabın son öyküsü olan “Tin Kovukları"nda diğer kahramanların da içinde bulunduğu trenin geldiği istasyondur. Peyman'ın pimini çekmiş olduğu bomba aslında kendi hayatıdır. Pim, intikamın metaforu olarak karşımıza çıkar.

\section{Sessizlikte}

Öykünün kahramanı olan kız psikiyatr servisinde tedavi olan bir hastadır. Kız küçükken eve sürekli sarhoş gelen babası yüzünden sinirlenen annesi evini ateşe verir. Yangından sonra küçük kız korkudan konuşamamaya başlar. Annesi ve babasıysa hayatını kaybeder. Annesi evi yaktığı zaman amcası Korkulukadam da oradadır ve kız yangından kaçıp koşarak onun yanına gider. Şimdilerde ise hâlâ hastanede tedavi altındadır. Bazen hemşiresi onu, evini ve amcasını ziyaret etmesi için evine götürür. Her ziyarete gidişinde Korkulukadam (amcası) ona eski fotoğrafları gösterip fotoğraflardaki kadının annesi olduğunu söyledikçe kız çok sinirlenir. Çünkü o annesini elinde taşıdığı bebek zannetmektedir, amcasının gösterdiği kadının annesi olduğunu kabullenemez, amcasının gösterdiği kadın kızın kendi kurduğu dünyasındaki yengekadındır. Ayrıca kız evdeki piyanoyu da kendine çok yakın bulur, kendiyle bağdaştırır çünkü piyano da yangından sonra kız gibi, sesini kaybetmiştir.

\section{Düşten Kanatlar}

Kitabın en uzun öyküsü "Düşten Kanatlar"dır. Öykü 2006'da KASAİD 10. Geleneksel Kadın Oyunları ve Öyküleri Yarışması Üçüncülük Ödülü’ne layık görülür. Eserin başkahramanı Şerife'dir. Şerife küçük yaşta babası tarafından kendisinden yaşça büyük biriyle evlendirilmek istenir fakat o bu evliliği istemez. İstemediği kişiyle evlenmemek için okulun servis şoförü 
Hüseyin'e kaçar. Şerife'nin evlenmesini istemeyen tek kişi Hoc'abla ${ }^{2}$ dediği öğretmenidir. Şerife boş zamanlarında öğretmeninin oğlu Arda'ya bakmakta, ona çeşitli masallar anlatıp bakımını üstlenmektedir. Şerife'nin servis şoförüne kaçtı̆̆ını duyan öğretmen çok üzülür fakat elinden bir şey gelmez.

Şerife Hüseyin'le evlendikten sonra çok acı çeker. Kocası işi bırakır ve evin geçimini sağlamak Şerife'nin üstüne kalır. Şerife'nin eziyetli bir de kaynanası vardır. Çocuğu olmadığından dolayı kocası Şerife'nin üzerine kuma getirir ve yeni gelinin eve geldiği gece Şerife dayanamaz ve göğüslerini keser. Aylarca yoğun bakımda yatar ve iyileştiği zaman artık kimsesiz kalan Şerife'ye hastanenin başhekimi hastanede iş ayarlar. Bir süre burada çalışıp işleri öğrenir fakat hastaneden bir personel tarafindan taciz edilmeye dayanamaz ve onu yaralayıp kaçar. Şerife için bundan sonrası bambaşka bir hayattır çünkü artık erkek kılığına girip o şekilde yaşamaya karar verir. Başhekim sayesinde yeni bir kimlik edinir. Adını Şeref yapar. "Adımı yazma. On iki yıl saklamışım kendimi. Herkes Şeref diye tanır beni. Bir Başhekim Bey bilirdi hikâyemi, o da dört yul oluyor, rahmete kavuştu." (s.29) Sonra otoparkta araba yıkama işine girer ve orada yaşamaya başlar. Başhekim öldükten sonra evinin huzurevine çevrilmesini ister fakat Şerife'nin çalışmış olduğu otopark zincirinin sahibi adam mafyadır ve başhekimin evini yağmalamaya karar verir. Bu kadarına katlanamayacağını düşünen Şerife karakola giderek durumu haber verir. Komiserin yönlendirmesiyle de otopark sahibini arayıp memlekete gittiğini söyler. Şerife karakoldayken bir zamanlar bakıcılığını yaptığı Arda'yı çağırtır. Onun fotoğrafını daha önce bir gazetede görüp gururlanmış, gazeteci olan Arda'ya istediği zaman nasıl ulaşabileceğini anlamıştır. Artık hayatı için dönülmez bir yola girdiğini anlayınca onu çağırtır ve başından geçen her şeyi daha önce kimseye anlatmamışken ona uzunca anlatır ve bunları adını gizli tutarak yazmasını ister. Arda için Şerife masallarda anlattığı Gün Perisi, Şerife içinse Arda, Cesur Prens'tir. "Gözlerim ilahemde, büyülenmişim. 'Çıkmıycam, senle oynayalım. Sen Gün Perisi ol, ben Cesur Prens.' Yanağımdan makas aliyor." (s. 29)

Hayat karşısında sürekli savaşmış Şerife artık düşten kanatlarını kaybetmiştir. Onun düşten kanatları, onu hayatta tutan hayalleridir. Yaşadıklarından dolayı da bu kanatları yok olmuştur. Öykünün ana kahramanı Şerife'dir. Küçük yaşta evlendirilmemek için bir başkasına kaçmış, eziyet görmüş, üzerine kuma getirilmiş, bu yüzden öfkelenip gögüslerini kesmiş ve

\footnotetext{
2 (Alanyalı, 2017, s. 30)
} 
daha sonra erkek gibi yaşamaya başlamıştır. Bu öyküde karşımıza çıkan kadın kahraman hem çokça acı çekmiş hem de bu acılar karşısında güçlü durmayı başarabilmiştir. Çocuğu olmayan kadınların kalmış olduğu toplumsal baskı, kadının toplum içindeki yerini anlatan bu öyküde yine kahramanın psikolojisi ön planda tutulmuştur. Bozkır Gecesinde Bir Tren kitabında birçok öykü, örneği verilen öykü gibi kişilerin psikolojisi ön planda tutularak ele alınmıştır.

\section{Altın Dișli Pakize}

Mahalleye yeni taşınan bir ailenin öyküsüdür. Sessiz, tekdüze hayat yaşayan mahalleliler Pakize'nin gelmesiyle hayrete düşerler çünkü dişleri bile altından olan Pakize mahalledeki diğer kadınlara benzememektedir. Kahkahası her defasında tüm mahalleyi çınlatır, mahalleli kadınların asla yapmadığını yapar ve müzik sesi duyduğunda gerdan kıvırır, yüksek sesle şarkılar söyler ve bunları yapmaktan asla çekinmez. Kocası da oldukça sessiz bir adamdır. Pakize'nin her sabah bir yerlere gitmesi mahallelinin dikkatinden kaçmaz. Hem onun davranışları hem her sabah bir yerlere gitmesi mahallede fisıltılara sebep olsa da bir yerden sonra herkes bu duruma alışır ve Pakize'yi kabullenirler. Bir gece mahalleli kavga sesiyle uyanır. Gece vardiyasında olan koca mahalle bekçisinin haber vermesi üzerine eve gelir ve karısını aşığıyla yakalar, kendine hâkim olamayıp karısını öldürür. Öfkesi o kadar fazladır ki dayanamayıp karısının ağzındaki sekiz altın dişi söker ve altın dolu kollarını baltayla kesip şoktaki oğlunun üzerine firlatır. Ertesi gün bu olaylar gazetede yer alırken Pakize'nin söylediği son sözlere yer vermezler.

"Ula, kendi gönlümle olunca mı dokundu? Ucunda altın yok, he mi? Hay canına yandı̆̆ımın..." (s.51)

“Altın Dişli Pakize" olayın ön planda olduğu bir öyküdür. Bazı hayatların göründüğü gibi olmadığını anlatması yönüyle de önemlidir. Ayrıca bu öyküde kadının toplumdaki yeri sorgulanırken karısını ucunda para olmayan bir ilişki için öldüren koca da eleştirilmektedir. "Altın Dişli Pakize" de işlenen cinayet her ne kadar namus meselesi gibi gözükse de adam karısının aşığıyla olan birlikteliğinden para gelmeyeceğini bildiği için karısını öldürmüştür.

\section{Duvara Karşı Balık Kız}

Öykünün kahramanı genç kız bir sergide gördüğü resme karşı tarifsiz duygular hissetmeye başlar. Resmi gördükten sonra uzun zaman etkisinden çıkamaz ve ertesi gün okulun kapısından sergiye gitmek için döner. Sergide gördüğü resimde bir balık kız vardır ve bu kız kendisiyle konuşur. " $O$ günden beri iki kişiyim. O ses... Ne uğraşlara odaklanabiliyorum, ne ufukta bir çözüm... Günlerin yükü ayaklarıma dolanıyor. Sergi yakında bitecek. Beynimdeki burgu sonsuzca dönüyor. Olmayacak böyle. Onu yeniden görmeliyim. " (s.53) Sonraki 
gün genç kızın kendini yine resmin başında bulması ressamın da dikkatini çeker ve kıza resmin kendisi için çok özel olduğunu, resmin onunla konuşup konuşmadığını sorar. Sonrasında ressam, kıza tabloda yer alan kişinin kızı olduğunu, bir tartışma sonucu kızının denize atlayarak intihar ettiğini ${ }^{3}$ ve tablonun da bu durumu simgelediğini anlatır. Ressam, kıza tabloya bakamadığını, her gün günbatımında kısa bir süre tabloya bakıp sonrasında onu ters çevirdiğini, tablodan tek beklentisinin bir kez olsun kendisiyle konuşması olduğunu belirtir. Ayrıca bundan sonra bu gizemli tabloyu (tablo genç kızla konuştuğu için) istediği takdirde sadece ona gösterebileceğini ve isterse bunun için atölyeye gelebileceğini söyler. Yıllar sonra kız, tabloyu yeniden görmek için atölyeye gittiğinde duvarda ressamın adını ve altında "Anisına, saygıyla..." (s.57) yazısını görür. Görevlilerden ise de ressamın bir gün bilinmedik bir tablonun külleri arasında cansız yattığını, yanık çerçeveye sarılmış hâldeyken bileklerini keserek intihar etmiş olduğunu öğrenir.

Öykü beş bölümden meydana gelmiştir. Pişmanlık duygusu yaşayan bir babanın çektiği ıstırabı anlatır. Genç kızın ve babanın psikolojik durumları okuyucuya aktarılırken olağanüstülük de kullanılmıştır.

\section{Bütün Kara Parçalarında}

Kitabın sekizinci öyküsü olan "Bütün Kara Parçalarında" 2006'da Cemal Süreya'yı anarak yazılmış küçürek öyküdür. Coğrafya sınavı olan liseli bir genç hazırlanıp gidecekken anne ve babasının konuşmalarına şahit olur. Çocukları okusun diye baba kendi giyeceği paltoyu eskiciden alıp bunlarla idare etmeye çalışır. Paltoyu aldıktan sonra da ellerinde sadece çocuğun yol parasını karşılayacak para kalır. Bunu duyan genç koşarak babasına sarılır ve kendini onların emeklerini kemiren bir güve gibi hisseder. Genç, suçluluk duygusunun bütün kara parçalarında gri olduğunu söyler. "Suçluluk duygusu bütün kara parçalarında gridir. Bizimki dâhil. Coğrafya sınavlarında bu hiç sorulmayacakttr." (s. 59) Ayrıca öyküde Cemal Süreya'nın Üvercinka şiirine gönderme vardır. Şiirin her bendinin sonunda yinelenen "Bütün kara parçalarında" dizesi öykünün başlığıyla ortak olduğu için yazar öyküsünü Cemal Süreya'yı anarak bitirir.

\section{Gökyüzü Gibi}

"Gökyüzü Gibi” adlı öykü de Edip Cansever'i anarak yazılmış küçürek bir öyküdür. Annelerini kaybettikleri gün ikiz kardeşler küçükken oynadıkları

\footnotetext{
${ }^{3}$ Babayla kızın arasında çıkan kavga kızın erkek arkadaşıyla alakalıdır. Öyküde satır aralarında sunulan bilgilerden bu kavganın kızın erkek arkadaşıyla birlikte olmasından dolayı çıktığı anlaşılmaktadır. Yazarın intihar eden genç kızı bir balık kız olarak ifade etmesinin de sebebi budur çünkü balık kızın belden aşağısı, bacakları, yoktur.
} 
oyunu hatırlarlar. Annelerinin eteğinin altına saklanıp saklambaç oynamalarını gelir akıllarına. Annelerinin cenazesini almaya gelen kamyonetin sürücüsü, iki çocuk ve onları kovalayan iki yetişkin adam görür. Öykü, Edip Cansever'in “Gökyüzü gibi bir şey bu çocukluk, Hiçbir yere gitmiyor." (s.60) dizelerine yer verilerek bitirilir.

\section{Bana Keman Çal}

"Bana Keman Çal" adlı öyküde genç bir kadının kendisinden yirmi yaş büyük sevgilisini sevmediği hâlde kendini sürekli onun yanında bulması anlatılır. Kadın, adamın keman çalmasını çok beğenmekte adeta büyülenmekte fakat adamı sevmemektedir. Her defasında neden adamın yanında olduğunu sorgulasa da sonrasında yine onun yanında kendini bulur ve sevgilisinden sürekli keman çalmasını ister. "Sokaklardayım tekrar. Biliyorum, telefonsuz geçen beş-on günün sonunda o dağınık, tozlu evin klş güneşine döneceğim. Bu hep böyle oluyor. Onu sevmeyişimin ve geri dönüşlerimin nedenleri askıda." (s. 62)

$\mathrm{Bu}$ öyküde alışkanlıkların insan hayatına hükmetmesi anlatılmaktadır. Kadının adamı sevmediği hâlde onun keman çalmasına olan tutkusu bu hükmetmeye örnektir.

\section{Eskidik}

Bakkal Sebati Efendi'den peynir almak için dükkâna giden Şükran Hanım alışveriş sırasında derin düşüncelere dalar. Önceden ekonomik açıdan daha rahat olduğunu oysa şimdi peynir alırken bile düşünmek zorunda kaldığını fark eder. "Bilmiyor muyum sanki! Peynirin iyisiyle tattığım arasındaki farkl, çantamdaki paradan çok. Bir vakitler her şeyin iyisini seçmek için tadardım ya... Ăgzım acı." (s.64) Mahalle bakkalının ve kara kaplı defterinin samimiyetini süpermarketlerde bulamadığını, Sebati Efendi'nin dükkânının da eskisi kadar dolu olmadığını da fark eder. Ayrıca babasını kaybetmiş, evlenmemiş olan Şükran Hanım bir anda gençliğini anımsar fakat Sebati Efendi'nin sesiyle kendine gelir.

Süpermarketlere, kredi kartıyla harcama yapmalara ayak uyduramayan Şükran Hanım'ın öyküsüdür. Babası vefat etmiş, zamanında hoşlandığı Ömer Bey çekip gitmiş, evde kalmış, mutsuz bir kadındır Şükran Hanım. Sebati Efendi'nin bakkalı da önceden çok daha doluyken artık eskisi kadar dolu değildir. Öyküde zayıf düşen bakkalla Şükran Hanım arasında paralellik vardır. Bakkal dükkânı gibi çöken yine de güçlü durmaya çalışan bir kadın anlatılmıştır. 
Gazi

İnsanoğlunun kertenkele misali zorluklar karşısında kuyruğunu bırakıp kaçsa bile bir yenisini daha çıkartmadığını anlatan, savaş karşıtı, savaşı eleştiren küçürek bir öyküdür. Öykü bir gazinin üzerinden anlatılmıştır. Yarım gövdesini taşıyan arabanın tekerini döndürmeden önce: "İnsanoğlu bir kuyruk olsun çıkartamıyor. " (s.68) diyerek uzaklaşır.

\section{Üvey}

Çocuğun, babasıyla arabada giderken babasının durakta durup kırmızı şemsiyeli esmer bir kadını arabaya alması ve arabanın genişleyip eve dönüşmesi anlatılır. Arabanın eve dönüşmesi kırmızı şemsiyeli kadınla adamın evlenmeleridir. Öykünün son cümlesi "Evin sobası yandl, üzerindeki kestaneler mis gibi koktu." (s.69) ifadesiyle de mutlu ve sicak bir yuvanın kurulduğu okuyucuya aktarılır. Kestane sıcak, mutlu, huzurlu bir yuvanın simgesi olarak okuyucuya sunulur.

\section{Yol Arkadaşı}

Mehmet karavanıyla kasabadan geçerken çocukluk arkadaşı Fahri ile karşılaşır ve karavana binip kafa dağıtmaya giderler. Sahile yakın bir yerde oturup dertleşirlerken Fahri geçmişini hatırlar ve ağlamaya başlar. Arkadaşını bir türlü susturamayan Mehmet, 1slanmanın ona iyi geleceğini düşünerek onu denize sürükler. İlk başta sakinleşen Fahri sonrasında soyunur ve bağırarak: "Fahri'yim ben! Bakırcılar'in Fahri! Aynıyım, benim hâlâ! Göğüslerime değil, yüreğime bakın! Yüz çevirdiğiniz Fahri'nin özüne bakın!" (s.73) der. Sonra çıplak hâlde koşarak Mehmet'e sarılır ve o esnada birkaç flaş patlar. Ertesi sabah bir turist karavana gelerek çekmiş olduğu fotoğrafi Mehmet'e verir.

Öykü Mehmet'in karısına yaptığı açıklamalardan oluşmuştur. Karısı, kocasını kıskanır çünkü kocasının getirdiği fotoğrafta eşi ve bir kadın vardır. Mehmet ise eşine başından geçenleri anlatarak ikna etmeye çalışır. Meğer Mehmet'in çocukluk arkadaşı Fahri ameliyat olup cinsiyet değiştirmiştir ve bu kadar dertli olmasının, ağlamasının sebebi de kasaba halkı tarafından dışlanmasıdır.

Olay örgüsü karş1lıklı konuşma şeklinde değil de sadece Mehmet'in konuşmaları verilerek aktarılmıştır. Karısının eşine verdiği cevaplar doğrudan verilmemiş, Mehmet'in verdiği cevaplarla okuyucuya hissettirilmiştir. "Allah için, en keyifli gezilerimden biriydi. Aaa, senin yerin başka elbet yapma n’olursun!' (s.71) Öykü Mehmet'in eşini inandırmasıyla son bulur.

\section{Gitmek}

"Gitmek" bir bunalım öyküsüdür. Artık yaşlı, eksilmiş ve aynı yolu paylaşması mümkün olmayan kahraman çift her zaman gelip oturdukları 
bahçeye yine gelirler ve ayrı ayrı düşüncelere dalarlar. Aslında onların gittikleri ilk yer kendi duygu ve düşüncelerinin akışıdır. Bu duygu ve düşüncelerle ilk olarak gençliklerine giderler. Kahramanların üzerlerinde gençlik dönemlerine dalmanın verdiği bir dinginlik vardır. Bekledikleri otobüs onları gençliklerine götürecek unsurun metaforudur. Yinelenen "Bir serinlik artyorduk."(s.75) cümlesindeki serinlik de gençlik yıllarının metaforu olarak aktarılır. Kitaptaki birçok öyküde olduğu gibi bu öykünün de başkişisi kadındır. Olaylar kadının ağzından anlatılmaktadır.

\section{Kayıр}

Umudunu ve güvenini kaybetmiş birinin öyküsüdür. Bu kişi sürekli arayış içindedir fakat umudunu nerede ve ne zaman arayacağını tam olarak bilemez. "Neydi, küle umut ekmenin mevsimi?" (s.77) diyerek sürekli kendini sorgular. Aradığı umudu ise bozkırın ortasında bir trende bulur. Yolculuk yaptığı trende doğan bebek onun umutlarını yeşertmiştir. Bu yüzden bebeğin adının Umut olmasını ister. Yazarın, öykünün kahramanı üzerinden okuyucuya vermek istediği mesaj ise umudun gelecek kuşaklarda olmasıdır ve arayan herkesin bir gün mutlaka onu bulacağıdır. Umut, gelecek kuşakların da simgesidir.

\section{O Eski Oyun}

"O Eski Oyun" adlı öykü, bir kadının küçükken ağabeyiyle buldukları oyunu uzun yıllar tek başına bile oynamasını anlatır. Oyun, ş̧ık yanan her evde nasıl hayatların olduğu tahmin etmek üzerine kurulmuştur. "Her pencere, bir kitap kapağıydl. Işıklara göre belirleniyordu içerik.” (s.78) Floresanlar çocuğa soğuk, kısa, diyalogsuz öyküler yazdırırken kristal avizeli evler şımarık öyküler yazdırır. Çıplak ampullü evler yoksul insanların hayatını çağrıştırırken kimi 1şıklarsa çocuğun düşüncelerini özgürleştirir. Kadın büyüdüğü zaman bile oyunun etkisinden çıkamaz ve gördüğü her 1şığa farklı öyküler yazar. Kendi evinin perdelerini ise başkaları 1şığını okuyup öyküsünü yazsın diye kapatmaz. Öykünün sonunda kadının ölümü ve öldükten sonra farklı bir boyutta bile bu oyunu oynayacağı sezdirilir.

\section{Aşkların Eski Tadı Yok}

"Aşkların Eski Tadı Yok" üç ayrı sesin oluşturduğu bir öyküdür: Alkolik B., papağan ve televizyondaki ses. Alkolik B. televizyon karşısında rakı içerken sarhoşluğun verdiği hâlle televizyondaki filme cevap vermeye başlar. Televizyonda gördüğü kadını sevgilisi zanneder. Oysa hepsi sarhoşlukla kurduğu hayallerdir. Üç sesin birbirine karışarak oluştuğu öyküde yazar, satır aralarında verdiği küçük ifadelerle metni okuyucunun zihninde tamamlamaya çalışmıştır. "Tünekteki, yankıladl. Alkolik! Alkolik!” (s. 81) diyerek verilen 
seslerden birinin papağana ait olduğunu belirtir. "Kapatma düğmesine bastı." (s.82) diyerek diğer sesin televizyona ait olduğunu okuyucuya hissettirmiştir.

\section{Son Yolcuyu Beklerken}

Yalnız bir kadının öyküsüdür. Kahramanın cinsiyeti öyküyü okurken söylenmese de kitabın son öyküsünde kadın olduğu anlaşılmaktadır. Kadın bir akşam yemek yerken eski sevgilisini aramak ister fakat arayamaz. Onu ancak hayalinde arayabilir. "Havada numaranı tuşluyor parmaklarım."(s.83) Kadın kendini çok yalnız hissettiğinden dolayı yemek yerken tabağındaki lüferle konuşmaya başlar. "Şerefe, dostum Lüfer! Tanıdım sizi. Bu gece burada ve yarım olma üzre bir efkâr... Bir olta mıydı inandı̆̆ınız, ă̆ miydı yoksa? Ben? Hayallere inanırım ben..." (s.83) Hayalinde sevgilisinin numarasını tuşlayan kadın onu bulunduğu yere çağırır; fakat gerçekte onu aramaz. Bilir ki, kimse gelmeyecektir. Hep biraz eksik yaşayacağını düşünür.

\section{Başucu Dilekleri}

Evladı yoğun bakımda ölümle pençeleşen bir annenin öyküsüdür. Anne şehirlerarasında çalışan bir otobüsün çarpması sonucu yoğun bakıma kaldırılan çocuğunun uyanmasını umutla bekler. Tüm acılarına rağmen güçlü durmaya çalışır. "Gençliğini takıyorum boynuma. Gırtlağımda düğümleyip sokaklara çıkıyorum. Bütün saatleri bir dakika geri alıyorum. Bütün ışıkları kırmızıya. Yolundaki taşları topluyorum." (s.84) Yazar, sevdiklerini kaybetme korkusunun nasıl olduğunu bu öyküdeki umutla bekleyen annenin üzerinden okuyucuya sunmuştur. Olaylar, annenin acısına şahit olan üçüncü bir kişi tarafindan anlatılmaktadır.

\section{Saklı Bilgi}

Kocası hapiste olan kadın yalnız yaşamaktadır. Bir gün eşinin kardeşi Armağan- telefon ederek yurtdışından arkadaşının geleceğini ve onu misafir etmesini ister. Kadın havaalanına gider ve yanında biriyle eve döner. Üç hafta birlikte yaşadığı misafirini oldukça soğuk bulur, onun gözlerine bakmaktan korkar, tedirgin olur ama onun gözlerine bakmadan aynı evde yaşamaya da alışır. "Zamanla Runa'ya alıştım. Bunu gözlerine pek bakmayarak yaptım." (s.87) Sonrasında misafiri gider. Aradan birkaç gün geçer ve Armağan yengesini arayıp planın değiştiğini, arkadaşının bu hafta geleceğini söyleyince kadın üç hafta kiminle yaşadığını sorgulamaya başlar. Kadın, bir yabancıyla birkaç hafta boyunca aynı evde yaşadığını fark edince ürperir. Aslında kadının üç hafta aynı evde yaşadığı kişi kendisidir fakat o bunu fark etmemiştir. Yalnız olması, kocasının hapiste işkence görmesi kadının akıl sağlığını bozmuştur. "Burada kırık bir ayna buldum. Yatağımın altında sakllyorum. Beyazlı adamlar çekilince çıkarıp gözlerime baklyorum. Bu zehir yeşili korkutuyor beni. 
Baktıkça bir şeyler uçuşuyor zihnimde, yakalayamıyorum. Sanki biri durmaksızın fisildiyor. 'Burada hayat zehirli' diyor." (s.89) Öykünün sonundaysa kadın akıl hastanesine yatırılır.

\section{Kapalı Perde}

Dört bölümden oluşan öykü bir muhabirin hayatını konu edinir. İlk iki bölümde muhabirin bir sergide gördüğü, iki kişinin el ele tutuşup öne çıktığı, sahnedeki son selam anını betimleyen tabloyu görüp, ondan etkilenerek tabloyu satın alması anlatılır. "Sadece katkı olsun diye değil,; sanki bilinmez bir efsunla bağlandım ona. Ressamın firçası içimden geçenleri söylüyor. Sanki o tabloyu alırsam hepsi iyi olacak, hep ömürlerini adadıklarl o anın hazzında...” (s. 90) Üçüncü bölümde, çalıştığı kurumdaki müdüründen nefret edip istifa etmeyi düşünen muhabirin hasta yatağında son günlerini yaşayan, gırtlak kanseri olup sesini kaybeden sanatçıya hak ettiği veda haberini yapmadan istifa etmek istememesi anlatılmıştır. Ayrıca bu bölümde hasta yatan sanatçının muhabire bu sektörde onun gibi insanlara ihtiyaç olduğunu söylemesi ve istifa etmeyip dayanmasını istemesinden de bahsedilir. Sanatçı muhabire gizli mabedini de açmıştır. Orada sanatçının kaybetmiş olduğu eşinin sahne eşyaları vardır. Dördüncü bölümdeyse bir gün sahne aydınlanır ve hasta sanatçı repliği olmadan, yeşil örtüye sarılı sahneye son kez çıkar. Böylelikle muhabir son haberini yapmış olur. Sergiden almış olduğu tablodaki kişilerin yüzleri her ne kadar belli olmasa da muhabir onların kim olduğunu çok iyi bilir. "Yüzleri yok ama kim olduklarını biliyorum. Onlar hep sahnede. Ömürlerin adandığ bir anda kalmışlar, el ele. İçim rahat. Perde!" (s. 93) Bu öyküde okuyucuya hissettirilen en yoğun duygu vefadır. Ayrıca medyanın insanların özel yaşantılarını fazla ele almasına da bir eleştiri söz konusudur.

\section{Tin Kovukları}

Kitabın en son öyküsü "Tin Kovukları"dır. Bozkırın ortasında ilerleyen tren aniden bozulur ve trendekiler parça gelene kadar beklemek zorunda kalırlar. Yolcular beklerken kırmızı şemsiyeli esmer kadının doğum sancıları başlar. Doğan bebekle ilgili her yolcu hayatını da göz önünde bulundurarak kendi kendine yorum yapar. Öykünün en önemli özelliği diğer öykülerin kahramanlarının ya da kahramanlarla münasebeti olan kişilerin trende bulunmasıdır. Yazar her paragrafı bir öyküye ayırmıştır. Ayrıca diğer öyküler hakkında ipuçları da burada verilir. Meselâ "Son Yolcuyu Beklerken" adlı öyküdeki başkahramanın kadın olduğu burada belirtilir. Eser, "Pim" öyküsünün başkahramanı olan Peyman'ın gara girip canlı bomba olarak kendini patlatmasıla son bulur. "Gara gebe bir kadin girdi. Peronun kalabalığına yürürken karnını yokladı belli belirsiz. 'İyi, bitecek yakında.' 
Gülümsedi. Eli mantosundan içeriye uzandı. Tindeki kovuklar, kısacık bir anla doluverdi. Kırmızı. Sonra, sessizlik başladı.” (s. 97)

Yirmi üç öyküden meydana gelen kitap yolcunun öyküsüyle başlayıp tren yolculuğuyla sona ermiştir. Yol, hayatın metaforu olarak karşımıza çıkar ve son öyküdeki yolculukla da hayat sona erer. Eserdeki bütün öyküler birbiriyle bağlantılı değildir fakat son öykü diğer öykülerle bağlantılıdır.

\section{Berat Alanyalı'nın Öykücülüğg̈}

Öykülerinde genellikle yalnızlık, yanlış tercihler, pişmanlık gibi gerçek yaşamda yer edinen konuları işleyen yazarın öykülerinin birçoğunun başkahramanı kadınlardır. Seçilen kadınlar hayatın farklı yönlerini yansıtmaları açısından da önemlidir. İçlerinde eğitim almış olanlar olduğu gibi eğitimsiz olanlar da vardır. Mutsuz kadınların yanı sıra mutlu olanlar da bulunmaktadır.

Yazarın incelemeye esas aldığımız eserindeki bazı öyküleri ${ }^{4}$ okurken kahramanların cinsiyetleri, meslekleri açıkça belirtilmemiştir fakat son öyküde bu kişilerle ilgili ipuçları verilerek kimlikleri meydana çıkarılmıştır. Sadece "Bütün Kara Parçalarında", "Gökyüzü Gibi”, "Gazi”, "Yol Arkadaşı", "Aşkların Eski Tadı Yok" öykülerinin başkahramanı erkektir. Kitapta yalnızca "Pim”, "Düşten Kanatlar", "Altın Dişli Pakize", "Eskidik", "Yol Arkadaşı", "Aşkların Eski Tadı Yok", "Saklı Bilgi” öykülerinin kahramanlarına isim verilmiştir. Diğer öykülerde kahramanlar sıfatlarıyla ön plana çıkarılmıştır. Yedi öyküde ${ }^{5}$ ölüm konusuna değinilmiştir. Yedi öyküde ${ }^{6}$ ise kişilerin kendilerini ya da hayatı sorgulamaları anlatılıp on beş öyküde ${ }^{7}$ geçmişi anımsama, geçmişi düşünme söz konusudur. Bütün öykülerde ise kişilerin psikoloji ön planda tutulmuş olup yaşanan olayların onlarda oluşturduğu etki aktarılmıştır.

Yazarın öykülerindeki kurgu gücü ve kişilerin psikolojini yansıtmada başarısı dikkati çekmektedir. Yazarın bu başarısında duygu ve düşüncelerini yansıtmak için kullandığı dilsel malzemeyi yer yer vurucu sembol ve mecazlarla kendine has üslubunun potasında başarılı bir şekilde eritebilmiş

4 "Yolcu" ve "Son Yolcuyu Beklerken" öykülerinin kahramanlarının kadın olduğu öyküleri okurken anlaşılmamaktadır.

5 "Küller ve Lavabo", "Pim", "Altın Dişli Pakize", "Duvara Karşı Balık Kız", "Gökyüzü Gibi”, "Kapalı Perde”, "Tin Kovukları".

6 "Yolcu", "Küller ve Lavabo", "Duvara Karşı Balık Kız", "Bana Keman Çal", "Kayıр", "Son Yolcuyu Beklerken", "Saklı Bilgi".

7 “Yolcu”, "Küller ve Lavabo", "Pim”, "Sessizlikte”, "Düşten Kanatlar”, "Duvara Karş1 Balık Kız", "Gökyüzü Gibi”, "Eskidik”, "Gazi”, "Yol Arkadaşı", "Gitmek”, "Kayı", "O Eski Oyun", "Son Yolcuyu Beklerken”, "Kapalı Perde".

http://dergipark.gov.tr/aicusbed 7/1 Nisan/April 2021 
olmasının da rolü vardır. Öyküleri okunurken zihinsel bir yorgunluk, konudan kopma gibi durumlarla karşılaşılmıyor. Akıcılık ve yoğunluk birlikte ilerliyor. Yazar, ayrıntılara boğulmadan duygu ve düşüncesini serin ve akıcı üslubunun da etkisiyle okuyucuya aktarabilmektedir.

Hayatın farklı yönlerini yansıtan öykülerini sunan yazarın dili de oldukça yalındır. Şiirsel ifadeler kullanması öykülerine renk katmıştır. Dil bilgisi kurallarına dikkat eden yazarın "Sessizlikte" öyküsünde "gizbahçe, rahmetlipeder, yengekadın, Korkulukadam"; "Gitmek" öyküsünde "tekülke, çokrenkli" sıfatları bitişik yazması dikkat çekicidir. "Altın Dişli Pakize" ve "Eskidik" adlı öykülerinde ise kişiler yöresel ağızla konuşturulmuştur. Essah, eyi olmuş? (s.48) Al komşi al... Mandalsiz ev olir mi?.. (s.67)

Berat Alanyalı eserinde etkilendiği yazar ve şairleri de anmıştır. "Bütün Kara Parçalarında" adlı küçürek öykü Cemal Süreya'yı anarak, "Gökyüzü Gibi” adlı küçürek öykü ise Edip Cansever'i anarak bitirilmiştir. "Başucu Dilekleri" adlı öyküde Lale Müldür'ün "Destina" şiirine, "Yol Arkadaşı" adlı öyküde ise Murathan Mungan'ın "Eskindendi, Çok Eskiden" şiirine atıfta bulunmuştur. Yazar, bir söyleşisinde etkilendiği yazarlarla ilgili “(...)̇̇lk öykü kitabım Tin Kovuğu'nda birer küçürek öyküyle saygı duruşunda bulunduğum Edip Cansever ile Cemal Süreya, benim denizlerimin en mavi yerlerinde akıyor. Deniz dibindeki kum tanelerini bir bir seçebildiğim duru sularda Memduh Şevket Esendal'dan başlıyorum yüzmeye, Sait Faik Abasıyanık'ın adasında soluklanıp tüm 1950 kuşağı öykücülerine selam duruyorum, bir yüce dağın eteklerinde.(...)" (http://www.edebistan.com/index.php/emineelifkotan/berat-alanyaliilesoylesi) diyerek düşüncelerini ifade eder.

\section{Sonuç}

Bozkır Gecesinde Bir Tren, Berat Alanyalı'nın 2007 y1lında Tin Kovuğu adılla basılan ilk öykü kitabıdır. Yazarın yazma serüveninin ilk ürünü olan bu eser, sonraki basımında Bozkır Gecesinde Bir Tren adıyla yeniden yayımlanır. Eserin adının değişmesi yazarın okuyucularına ulaşmasını ve eserin zihinlerde daha kalıcı olmasını kolaylaştırmıştır. Kitapta yirmi üç öykü bulunmaktadır. Birbirinden bağımsız öykülerin bulunduğu eserde son öykü, diğer yirmi iki öyküyle bağlantılıdır. Bu bağlantı, eserin bir bütünlük içerisinde olduğunu gösterir.

Bozkır Gecesinde Bir Tren adlı eserde kadın kahramanların ön plana çıktığı görülür. Böylelikle kadının toplum içerisindeki yeri ve önemi öykülerde vurgulanmıştır. Öykülerde kadın kahramanların dışında toplumun her kesiminden kişilere de yer verilmiştir. Yazar, bu şekilde tamamen kadın eksenli 
bir anlatımdan uzaklaşmıştır. Öykülere konu edinilen kişilere genellikle isim verilmemiştir. $\mathrm{Bu}$ durumda, kişiler toplumsal sıfat ve statülerinden çok psikolojik yönleriyle ön plana çıkartılır. Yazar, kahramanlarının psikolojilerini yansıtma konusunda oldukça başarılıdır.

Öykülerinde bireysel konuların yanı sira toplumsal konulara da değinen Berat Alanyalı, böylelikle ele alınan konular yönünden öykülerini daha zengin hâle getirmiştir. Ayrıca yazarın öykü ve küçürek öykülerinin akıcı, canlı, yoğun, şiirsel bir dili vardır. Böylece yazarın öyküleri tekdüze bir anlatımdan uzaklaşmış ve okuyucular için daha etkileyici bir hâl almıştır. Öykülerinde az sözle çok şey anlatan yazar özlü ve özgün eserler ortaya çıkarmıştır.

Bu çalışmada Berat Alanyalı'nın Bozkır Gecesinde Bir Tren adlı eseri yazarın öykücülügü etrafında genel hatlarıyla incelenmiş ve Alanyalı'nın dili, üslubu ve kurgusal bakış açısıyla özgün çalışmalara imza attığ 1 görülmüştür. Tüm incelemeler sonucunda yazarın edebî yolculuğunun ilk adımı olan bu kitapta, diğer kitaplarına göre fazla ayrıntılardan kaçınılmış ve öykülerde eksik bırakılan noktaların okuyucular tarafından bulunması daha çok istenmiştir. Böylece yazar ile okuyucu arasında görünmez bir köprü oluşmuştur. Son olarak, yazarın diğer eserlerine nazaran bu eserinde daha kapalı bir anlatım olduğu da görülmüştür.

\section{Kitap}

\section{Kaynakça}

Alanyalı, B. (2017). Bozkır Gecesinde Bir Tren . Ankara: Bilgi Yayınevi. Kolcu, A. İ. (2018). Öykü Sanatı (b.5). Erzurum: Salkımsöğüt, 15.

\section{Makale}

Edgü, F. (1997). "Çok Kısa Öyküler... Öykücükler". Adam Öykü (Kısa Kısa Öykü Özel Say1, 38-39), 12.

Korkmaz, R. (2007). "Küçürek Öykü (Short short story) Türü ya da Bir Çığlı̆̆ın Metinleşmesi". Hece Öykü, 19.

Shapard, R. (1997). "Kısa Kısa: Anlık Öykü". Adam Öykü (Özel Sayı: Kısa Kısa Öykü), 91-94.

Yumuşak, F. (2013). "Kısa Kısa [Küçürek] Öykünün Tanımı, İmkânları ve Sorunları". Erdem, 6.

İnternet Başlıkları

https://www.olay.com.tr/trende-birlesen-yollarin-hikayesi-71950 (Erişim Tarihi: 10.25.2020)

http://www.edebistan.com/index.php/emineelifkotan/berat-alanyali-ile soylesi (Erişim Tarihi: 15.09.2020) 